\title{
A difusão da dimensão cuidadora da saúde, a invenção de mundos e a comunicação do conhecimento como superfícies de contágio
}

O que hoje sabemos, com as pesquisas sobre a educação dos profissionais de saúde, é que, para que ocorram mudanças reais, além do ordenamento das políticas de formação, faz-se necessária uma mudança nos próprios modos de "pensar-sentir-querer" de quem opera as práticas de ensino na saúde, pois tecnologias do imaginário trabalham cotidianamente pela captura dos processos de mudança, fazendo-nos crer na defesa de seu contrário. Enquanto práticas cuidadoras seguem apontadas como polêmicas, complicadas, difíceis e arriscadas, surpreende-nos a defesa inesgotável ou renovada dos modelos liberais de exercício das profissões da saúde, da hierarquia de poderes sobre a compreensão e a decisão quanto aos fatores de promoção e de proteção da saúde e, ainda, das relações contratuais privadas sobre os modelos de atenção à saúde. As práticas cuidadoras a toda hora encontram argumentos de postergação, suspensão ou abandono.

As práticas cuidadoras em saúde podem ser resumidas como o exercício dos saberes profissionais no encontro com o usuário das ações e serviços de saúde. Esse é um lugar de aposta, não de convicções ou certezas, mas de oposição às posturas reativas à mudança. Uma tomada do pensar-sentir-querer será sempre uma aposta, requer um trabalho de educação no seu sentido mais forte: não será um trabalho de informação e nem de acomodação, será uma convocação ao aprender, um aprender de si e um aprender das novidades de si, assim como dos entornos e da criação. Se há um nó crítico às mudanças, a educação permanente, quando componente do trabalho e da educação na saúde, coloca as práticas individuais e coletivas cotidianas sob interrogação, questionando nossa capacidade de cuidado e de aceitação do novo. A difusão da dimensão cuidadora, a comunicação do conhecimento e a invenção de mundos emergem como superfícies de contágio: ativação do desejo de aprender e mobilização de encontros (instâncias onde ocorrem a interação e a produção de sentidos).

Pode-se destacar a dimensão cuidadora como o contraponto ao racionalismo e cientificismo (racionalismo lógico) da assistência à saúde. O cuidado viria para invadir e atormentar a atenção à saúde para que não se desocupe das aprendizagens com o outro, com a alteridade, com a afirmação da vida de sentidos. O humano é incerto, criativo, sensível às ousadias, sujeito às desestabilizações que alteram verdades; o cuidado precisa dessa correspondência. Brincando com a bela imagem de Fernando Pessoa, se o tratamento tem de ser preciso, o cuidado nunca será preciso. No viver humano não há precisão, não Ihe pode ser oferecida apenas a precisão da técnica (da navegação, falava Pessoa, referindo-se a correção em buscar a precisão para cruzar os oceanos, mas alertando que para com o viver não seria o mesmo, caindo indesejável tal busca). A atenção integral exige, para além da precisão, um "gordo" acolhimento. Neste número da Interface o Cuidado ganha projeção, não como uma teorização, mas como uma tematização.

Gostaria de destacar o quanto uma dimensão cuidadora da saúde representa de luta pela vida e o quanto temos nos afastado dessa condição, escolhendo vias e caminhos cheios de certeza burocrática, formalista, disciplinar e normativa. É por isso que a comunicação do conhecimento ganha um contorno especial quando entendida como superfície de contágio na difusão da dimensão cuidadora e na invenção de mundos. A comunicação do conhecimento em Interface tem essa oferta, esse é o convite de sua editoria, de seu projeto gráfico e de sua rede, nesses 11 anos da Comunicação, Saúde e Educação. O esforço de internacionalizar essa revista, hoje, não é o da sua projeção nas redes de captura da invenção, captura do cuidado ou captura dos compromissos com interesses públicos, mas o de encontrar enlaces para a invenção, o cuidado e os interesses públicos, em especial com parceiros da América Latina e da península ibérica.

Desafio posto à Revista é o de contribuir para a melhor expressão da inovação e do avanço da interdisciplinaridade na saúde: nem ciências naturais, nem ciências sociais, mas ciências do viver intensamente. A comunicação do conhecimento, a difusão da dimensão cuidadora da saúde e a invenção de mundos, nessa Revista, podem colocar-se como superfícies de contágio (interface)! Essa condição, um convite à sua leitura e escolha para a conversação. 